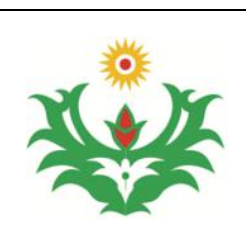

Linguistik Terapan 14 (1) (2017): 59-69

Jurnal Linguistik Terapan Pascasarjana

Available online

http://jurnal.unimed.ac.id/2017/index.php/JLT-Unimed

\title{
EXPERIENTIAL FUNCTION IN DONALD TRUMP'S SPEECH ABOUT RADICAL ISLAMIC TERRORISM
}

\section{HALIMATUN HUSNA RAMBE}

\author{
Siti Aisyah Ginting
}

Amrin Saragih

Linguistik Terapan Bahasa Inggris Universitas Negeri Medan

Diterima Februari 2017; Disetujui April 2017; Dipublikasikan Juni 2017

\begin{abstract}
This study deals with the Experiential Function in Donald Trump's Speech about Radical Islamic Terrorism. This study attempted to investigate the dominant elements of experiential function used in the speech, the realization and the reasons why the elements of experiential function are coded in the speech. This study was conducted by using qualitative design. The data in this study were the utterances of Donald Trump's speech transcribed in written mode. The speech is campaign speech about Radical Islamic Terrorism on August 15 ${ }^{\text {th }}$, 2016 at Youngstown State University. The research findings show that the dominant process found in the speech was material process, the dominant participant was actor and goal, and the dominant circumstance was location spatial and temporal. The processes were realized congruently and incongruently in metaphorical wording. Material process is dominantly used by Donald Trump about terrorism because he wanted to show the evil deeds done by terrorist and stimulate the listeners for future actions against terrorism, actor and goal participants show two confronting parties and circumstance location spatial and temporal show his point of view is authentic and objective.
\end{abstract}

\section{Keywords: Experiential Function, Speech, Terrorism}

How to Cite: Rambe, Halimatun Husna (2017).

Experiential Function in Donald Trump's Speech about Radical Islamic Terrorism. Jurnal Linguistik Terapan Pascasarjana Unimed, 14 (1): 59-69 


\section{INTRODUCTION}

There are two types of discourse, spoken discourse and written discourse. Spoken discourse uses more simple vocabulary and non-standard grammar. It also benefits from body language, gestures, intonation, pausing, rhythm, repetition etc. Meanwhile, written discourse is often planned, more complex, well-structured and transactional (Paltridge, 2006).

Political speeches are used by politicians to argue, to reason, to sustain their ideas, to continue in power, to oppress people and nations, to establish and perpetuate ideas, and or to defend people in their needs, to promote civil rights, and peace (Fairclough, 2000). So, political speech is an aspect of political discourse which concerned with political contexts, actors and with politicians, political institutions, governments, political media, and political supporters operating in political environments to achieve political goals.

Donald Trump took office as the 45th President of the United States on January 20, 2017. He harbored his political aspirations since 2000. Donald Trump's campaign slogan, "Make America Great Again" resonated with the American citizens. His tax plan calling for reducing the corporate tax rate to $15 \%$ and replacing the Affordable Care Act ("Obamacare") with a different free-market plan earned him support from several quarters.

Lakoff (2016), Director of the Center for the Neural Mind \& Society at the University of California at Berkeley, wrote about the use of language by Donald Trump in his personal website. He wrote Donald Trump simply uses effective discourse mechanisms to communicate what his wants to communicate to his audience. He had found that he is very careful and very strategic in his use of language.

Donald Trump's exact position on the Muslim registry remains opaque. He held a campaign event at Youngstown State University in Ohio on August 15, 2016. He discussed his plans about Radical Islamic Terrorism. He described a dozen high-profile terror attacks on domestic and foreign soil and blamed Democratic rival Hillary Clinton and President Barack Obama for the rise of ISIS. Now, Donald Trump is officially gunning for the Muslims. He initiates an immediate 90-day suspension of issuing visas to people from select countries, which currently are Iraq, Iran, Syria, Yemen, Libya, Sudan and Somalia. He has signed an executive order titled Protecting the Nation from Foreign Terrorist Entry Into the United States.

To understand better Donald Trump political intention at Youngstown State University in Ohio on August. 15, 2016, the study of systemic functional grammar with reference to experiential function is needed due to the processes help to reveal the meanings constructed by the speaker or writer (Halliday 
and Matthiessen, 2004). Fairclough also claims that choosing which process to describe the real happening bears “important cultural, political or ideological meaning” (1992, p.180).

Donald Trump clearly stated that Radical Islamic Terrorism has challenged the world especially America. He mentioned some examples of ISIS attack in America. For examples,

(1) 13 were murdered, and 38 wounded, in the assault on Ft. Hood.

(2) The Boston Marathon Bombing wounded and maimed

(3) In Chattanooga, Tennessee, five unarmed marines were shot and killed at a military recruiting center.

(4) Last December, 14 innocent Americans were gunned down at an office party in San Bernardino By such kind of description, Donald Trump doesn't clearly mention the agent of the attack, that is, the causer of the accident, consequently making it obscure who should take the responsibility. The readers just interpreted the attacker is ISIS due to the organization mentioned before. Meanwhile, when mentioning the attack in Europe, Donald Trump can clearly mentioned the agent. The examples can be seen below:

(1) In November of 2015, terrorists went on a shooting rampage in Paris..

(2) In March of this year, terrorists detonated a bomb in the Brussels airport,

(3) This July, in the South of France, an Islamic terrorist turned his truck into an instrument of mass murder,

(4) A few weeks ago, in Germany, a refugee armed with an axe wounded five people in a gruesome train attack.

The agent of the acts such as shooting rampage, detonating the bomb, turned the truck are clearly stated as "terrorist". "a refugee" is also considered as a terrorist because a hand-painted ISIS flag had been found among his belongings in his room. He made it clear who should take the responsibility. To be concluded, Donald Trump mentioned differently the person who responsible for the attacks happened in America and Europe.

There are some researchers that have analyzed the metafunction in many different politicians. Kondowe (2014) analyzed how the third Malawian president Bingu wa Mutharika manipulated language in his second inaugural address to enhance his political ideologies and Zheng (2015) reveals Bush's deeprooted ideology and the hidden ideology of Bush Administration.

In the other side, Koutchadé (2015) analysed the acceptance speech of the Nigerian Presidentelect, General Buhari and revealed that by using metafunction analysis has made it easy to highlight not only Buhari's experience of the events he has described, but also his persuasive strategies used in his speech. Liping (2014) had studied a political discourse from the perspective of transitivity. He found that 
Churchill tends to use more material and relational processes. The main purpose of Churchill's speech is to persuade British people to support his decision of assisting Russia and fighting against Hitler.

Nur (2015) took Nelson Mandela's presidential inauguration speech at Pretoria on May 10, 1994 as a sample to elucidate the role of Systemic Functional Grammar (SFG). She revealed that the architecture of Mandela's speech achieved his political purpose not only by corresponding with its lexicogrammmar but also by considering the contextual factors. Chinwe (2013) analyzed two inaugural speeches of two Nigerian past leaders; Alhaji Shehu Shagari (1979) and General Olusegun Obasanjo (1999), using the systemic functional grammar model propounded by Halliday. He has confirmed that the lexicogrammatical choices of transitivity in the inaugural speeches helped the readers in the interpretation of the experiential meanings of the two speeches.

Although some studies have investigated political discourse, different with the previous studies that discuss about experiential function in presidential speech, this research explores about experiential function that is found in Donald Trump's speech campaign about Radical Islam Terrorism, at Youngstown State University in Ohio on August. 15, 2016 may present dissimilar characteristics. Due to its functionality, this study aimed to explore the function and application of experiential function. By conducting the analysis in the political discourse, we would be able to reveal how the politicians initiate their discourse with the audiences or voters, establish the relationships and convince the voters via transitivity.

\section{RESEARCH METHODOLOGY}

This research applies qualitative research. This study tries to describe the experiential function found in Donald Trump's speech at Youngstown State University, in Youngstown, Ohio, $15^{\text {th }}$ August. The researcher also presents the frequency of the process and circumstance element that appear in that speech.

The data of this study were clauses found in Donald Trump's speech at Youngstown State University, in Youngstown, Ohio, 15 ${ }^{\text {th }}$ August, 2016. The topic of Donald Trump's speech at Youngstown State University was about "Radical Islamic Terrorism" . He talked about proposing the United States work with any country that opposes ISIS regardless of ideological differences, declaring anyone that wants to defeat the terrorist organization to be an ally. Trump will also expand upon his proposed Muslim ban, saying in his speech that as president he will order a suspension of visas to countries where adequate screenings can not be performed. He will also declare that the United States is at war with radical Islam. Finally, Trump blamed the rise of ISIS on President Barack Obama and on his opponent, Hillary Clinton, whose policies Trump argues allowed the terrorist group to grow. 
The source of data of this study is Donald Trump which gave speech about "Radical Islamic Terrorism" at Youngstown State University, in Youngstown, Ohio, 15 ${ }^{\text {th }}$ August, 2016 and the source of the data is taken from internet and in original form, downloaded from http://thehill.com/blogs/punditsblog/presidential-campaign/291498-full-transcript-donald-trump-addresses-radical. There were 400 processes within the 373 clauses.

In qualitative study, the human investigator is the primary instrument for collecting and analyzing the data. This is a unique role that qualitative researchers play in this research (Lincoln and Guba, 1985). So, the instrument for collecting the data is the researcher herself.

In collecting the data, documentary technique is used a suggested by Bogdan and Biklen (1992). Documentary was used since the data of this study is written or text based, especially transcript of the political speech about "Radical Islamic Terrorism" at Youngstown State University, in Youngstown, Ohio. Through this documentary technique, the collected data will be read and studied related to some books and references.

In data analysis, the researcher used the interactive model Miles, Huberman and Saldana (2014) state that this method consists of methodology by namely: data, condensation, data display and verification/ conlusion drawing.

Trustworthiness is the corresponding term used in qualitative research as a measure of the quality of research. Trustworthiness is the extent to which the data and data analysis are believable and trustworthy. Lincoln and Guba (1985) suggest that the trustworthiness of qualitative research can be established by using four strategies: credibility, transferability, dependability, and conformability.

\section{FINDINGS AND DISCUSSIONS}

Based on the analysis above, there were some findings could be revealed as the following;

1. Material process is the dominant process used in the speech, the most dominant participants are actor and goal, and the most dominant circumstances used in the Donald Trump's speech is spatial and temporal location.

2. The realization of experiential function is seen from the various transitivity configuration realized by the lexicogrammar. There are congruent realization and incongruent realization of experiential function.

Both congruent realization and incongruent realization of material process are found. Example 'In March of this year, terrorists detonated a bomb in the Brussels airport' is congruent because the actor fit to the logical function of the 'doing' thing in the process as 'terrorists' can 'detonated' something physically. The incongruent realization of material process is also found in the speech. The incongruent realization happened due to of the use of inanimate participant by which the actor doesn't 
have the capacity of human like that can physically do something, such in example "In the $20^{\text {th }}$ Century, the United States defeated Fascism, Nazism, and Communism'. 'The United States' represents the people of America.

Both congruent realization and incongruent realization of mental process are found. 'I believe' is in congruent realization because the participant is human and correspond to the verb 'believe'. Both congruent realization and incongruent realization of verbal process are found. 'I was saying this constantly' indicate a verbal activity by which the sayer 'I' expresses and utterance with 'this' as its verbiage.

The behavioral process in the text is only realized congruently. The realization is congruent because the use of behaver 'Pakistani girl' should do in her life are suitable to the behaver concept in behavioral process that the behavior has to be experienced by a conscious being. The existential process in the text is only realized congruently. Those are supported by the subject 'there' and the verb 'exists'.

Both congruent realization and incongruent realization of relational process are found. The congruent realization is realized in this example 'It is great to be with you this afternoon'. Here is the example of incongruent realization of relational process : Syria is in the midst of a disastrous civil war. The carrier 'Iraq' has been personified by referring it to the people of the Iraq nation.

3. Donald Trump used material process in order to express the examples of what the terrorists had done in America and Europe and what Donald Trump suggested to oppose all these threats in America and the courses to battle against Radical Islamic Terrorism.

Trump tried to expressed his cognitive processes such as 'have seen', 'listen', 'believe' , 'saw', 'recognize', 'know' and 'identified'. He used cognitive process 'recognize' and 'listen' to convey a meaning of mental collaboration from all sides to battle against terrorism.

The verbal processes are not only devoted to Trump but also to report a predicative verbal activity performed by others. Trump also informs people about he had in mind such as "my private doubts" and "that NATO was obsolete". Trump also interpose his own words to reassure listeners and by stating that 'his Adminstration' will speak out against the oppression of women, gays and people of different faith and suggested the listeners to state a mission.

There is only one clause that represents behavioural process. Donald Trump report the behavior that girls as the behaver did in their life. This relates to the case of a prominent Pakistani social media star that was killed by her own brother. The brother emphasized that girls are born to stay home and follow traditions. That is behavior that Pakistani girls should follow.

Existential process is used in two different clauses. In this two different clauses, Donald Trump represent the situation that had happened in America towards the existence of "an ISIS attack" and "the communism". 


\section{DISCUSSIONS}

Halliday (1985) defined that language is experience in relation to a scenario, some backgrounds of persons and actions and events which are said derive from their meaning. This is referred to the context of situation. It was necessary to provide information about what was happening at that time to interpret the meaning. A politician usually employs various processes to achieve his/her purpose. His/her purpose can be seen by analyzing elements of experiential function related to the context of the speech.

The findings reveal that the most dominant process is material process followed by Relational and Mental process, and minor processes which are Verbal, Existential and Behavioral. Material process takes the highest percentage $(58.8 \%)$ compared to other types. Semantically, material process indicate activities or event which happen in the outside world. Donald Trump used material process dominantly in order to express the examples of what the terrorists had done in America and Europe and what Donald Trump suggested to oppose all these threats in America and the courses to battle against Radical Islamic Terrorism. Donald Trump dominantly used the participant "We" in the speech.

These findings can be in coordination with the study of Liping (2014) "The Material and Relational processes are most often chosen in political discourse because they present the statements of reality from the point of onlookers. So they seem to be more objective than other processes". Furthermore, the fact that political discourse entail material process corresponds with the conclusions by Naz, Alvi and Albaseer (2011), Alvi and Abdul Baseer (2012) and Kondowe (2014).

The relational process is represented through the attributive and possessive process. Relational process is used to show the position of Donald Trump and Hillary Clinton. Liping (2014) showed similar results in his study on Winston S. Churchill's speech on Hitler's Invasion of the U.S.S.R that 'the relational processes are often used in explaining some abstract political concepts, elaborating the relationship between political powers or between entities. These findings are also similar to Harwiyati (2016).

There is only one clause that represents behavioral process. Donald Trump report the behavior that girls as the behaver did in their life. This relates to the case of a prominent Pakistani social media star that was killed by her own brother. The brother emphasized that girls are born to stay home and follow traditions. That is behavior that Pakistani girls should follow. Donald Trump represent the situation that had happened in America towards the existence of "an ISIS attack" and "the communism".

The dominant participants are actor and goal as part of material process. This happened due to the dominant process that was used in the speech is material process. The actors which are We, I, ISIS and terrorists are repeatedly mentioned in the text. They express the notion that had "done" and will do something. Meanwhile, the goals which are 264 people, five unarmed marines, 49 Americans are the notion had been done to and will be done to. The fact that ISIS terrorists did evils attack to America and 
Europe and Trump's determination of eliminating ISIS and Radical Islamic Terrorism are reflected in the use of language that has Actors and Goals, which involve the two conflicting parties.

The most dominant circumstances used in the Donald Trump's speech is location (spatial;place) with frequency $44(20 \%)$ and the number of circumstances extent (temporal;duration) is 17 (7.7\%), extent (spatial;distance) is 3 (1.4\%), location (temporal;time) is 35 (16\%), manner is 40 (18.2\%), cause $19(8.6 \%)$, contingency $30(13.6 \%)$, accompaniment $12(5.5 \%)$, role $10(4.5 \%)$, matter $7(3.2 \%)$ and angle $3(1.3 \%)$.

The circumstance location (spatial and time) is used to present the information about where and when the actions happened clearly. The circumstance extent (spatial and time) is used to explain the duration of the action happened. By using circumstances of spatial and temporal location frequently he makes his viewpoint authentic and objective. There are congruent realization and incongruent realization of experiential function happened in this text. The incongruent realization of material process happened due to of the use of inanimate participant by which the actor doesn't have the capacity of human like that can physically do something, such in example "In the $20^{\text {th }}$ Century, the United States defeated Fascism, Nazism, and Communism'. The incongruent realization of mental process is found in the speech. Example 'Iraq was experiencing a reduction in violence'. Incongruent expression of the use of the process by which the senser 'Iraq' doesn't have the capacity of human that can experience something psychologically.

\section{CONCLUSIONS}

Having analyzed the data by applying experiential function analysis, it is concluded that;

1) The most dominant process is material process followed by Relational and Mental process, and minor processes which are Verbal, Existential and Behavioral, the most dominant participants are actor and goal, and the most dominant circumstances used in the Donald Trump's speech is spatial and temporal location.

2) The transitivity realization of ideational metaphor cover almost all types of processes, including material, mental, relational, and verbal process. The discussion of metaphor nucleus is very essential to determine the pattern of metaphor. The incongruent realization of material process happened due to of the use of inanimate participant by which the actor doesn't have the capacity of human like that can do something physically, experience something, describe and say something.

3) The most dominant participants actor and goal participants show two confronting parties and the use of circumstance location spatial and temporal dominantly aims to show Donald Trump's point of view is authentic and objective. 


\section{REFERENCES}

Al-Haq, F.A. (2015). A Critical Discourse Analysis of Three Speeches of King Abdullah II. US-China Foreign Language, Vol. (13), No. 5, p; 317-332 doi:10.17265/1539-8080/2015.05.001

Ary, D., Jacobs, LC., Sorensen, C., and Razavieh, A. (2010). Introduction to Research in Education, 8th Edition. USA: Wadsworth.

Barton, E. (2006). Linguistic Discourse Analysis: How the Language in Texts Works. In C. Bazerman \& P. A. Prior (Eds.), What Writing Does and How it Does it: An Introduction to Analyzing Texts and Textual Practices. (pp. 57-82). London: Elbaum.

Baseer, A. \& Alvi, S.D. (2012). An Analysis of Barack Obama ${ }^{e e}$ s Speech „The Great Need of the Hour"e. In: Interdisciplinary journal of Contemporary Research in Business,3/9, 617-635. http://www.ijcrb.webs.com

Bell, M. (2001). Functional Grammar. New York: Longman

Bloor, T., \& Bloor, M. (1995). The Functional Analysis of English: A Hallidayan Approach. Beijing: Foreign Language Teaching and Research Press.

Bogdan and Biklen.(1992). Qualitative Research. London: Edward Arnold.

Bogdan, Robert and Taylor, Steven J.(1975). Introduction to Qualitative Research Method - A Phenomenological Approach to the Social Sciences. New York: John

Chinwe, Ezeifeka, R. (2013). Analysis of Experiential Meaning in Selected Inaugural Political Speeches in Nigeria. An International Journal of Language, Literature and Gender Studies. Vol. 2 (1) February, p:170-190 ISSN: 2225-8604(Print) ISSN 2227-5460 (Online)

Denzin, N. K. and Lincoln, Y.S. (1994). Handbook of Qualitative Research (2 ${ }^{\text {nd }}$ ed). Thousand Oaks, CA: Sage Publications.

Eggins, S. (2004). An Introduction to Systemic Functional Linguistics. New York: Continum.

Eggins, S. and Martin, J.R. (1994). An Introduction to Systemic Functional Linguistics. London: Pinter.

Fairclough, N. (1992). Discourse and Social Change. Oxford: Polity Press.

Gerot, Linda and Wignell, P. (1994). Making Sense of Functional Grammar. Australia: Antipodean Educational Enterprises.

Halliday, M. A.K. (1978). Language as social semiotic. The social interpretation of language and meaning. London: Edward Arnold.

Halliday, (1994), Introducing Functional Grammar. London: Edward Arnold.

Halliday, M. A. K., and Matthiessen, C. (2004) An Introduction to Functional Grammar. Beijing: Foreign Language Teaching and Research Press.

Halliday, (2007). Functional Grammar. 2 Edition. London: Edward Arnold 
Harwiyati, R. (2016). Transitivity System on Joko Widodo's Speech at the APEC CEO SUMMIT on November $10^{\text {th }}, 2014$, in Beijing, China. .Premise Journal. Volume 5 No.1. ISSN: 2442-482x (printed)ISSN: 977244248DD3 (electronic). P 160-171

Koutchadé, I.S (2015). Discourse Analysis of General Muhammadu Buhari's Official Acceptance Speech: A Systemic Functional Perspective. International Journal of English Linguistics; Vol. 5, No. 5; 2015 ISSN 1923-869X E-ISSN 1923-8703 doi:10.5539/ijel.v5n5p24 URL: http://dx.doi.org/10.5539/ijel.v5n5p24

Lincoln, Y.S., \& Guba, E.G. (1985). Naturalistic Inquiry. Beverly Hills, CA: Sage Publications.

Liping, C. (2014). Experiential Metafunctional Analysis of Winston S. Churchill's Speech on Hitler's Invasion of the U.S.S.R. School of Foreign Languages, Guangdong University of Petrochemical Technology, Guangdong, China. English Language Teaching; Vol. 7, No. 9; 2014 ISSN 19164742 E-ISSN 1916-4750. Published by Canadian Center of Science and Education.

Martin, J.R, Matthiessen. C, Painter.C. (1997). Working with Functional Grammar. Great Britain: J.W Attowsmith Ltd.

Martins, J. C. The exigence Iraq War in Tony Blair's speech to the Labour Party: an analysis. Revista Intercâmbio, Vol(5) No.26 p:183-195. São Paulo: LAEL/PUCSP. ISSN 2237-759x

Mayring, P. (2000). Qualitative content analysis. Forum: Qualitative Social Research, Retrieved July 28, 2016, from http://217.160.35.246/fqs-texte/2-00/2-00mayring-e.pdf.

Miles, M.B, Huberman A.M, Saldana. J (2014). Qualitative Data Analysis. USA: Sage Publications

Naz, S. and Alvi. (2012). An Analysis of Obama's Speech "Ending Iraq War, February 27, 2009" : A Halladian Approach. INTERDISCIPLINARY JOURNAL OF CONTEMPORARY RESEARCH IN BUSINESS. VOL (4) NO 8.

Nur, S. 2015. Analysis of Interpersonal Metafunction in Public Speeches: A Case Study of Nelson Mandela's Presidential Inauguration Speech. King Khalid University, Saudi Arabia.

Paltridge, B. (2006). An Introduction to Critical Discourse Analysis. London. MPG Books, Ltd

Sajjad, F. (2015). A Critical Discourse Analysis of Barack Hussein Obama's Political Speeches on the Middle East and the Muslim World. International Journal of Linguistics. Vol. 7, No. 1. ISSN $1948-5425$

Seidel, G. (1985). Political Discourse Analysis. London: academic Press.

Thompson, G. (2004). Introducing Functional Grammar. London: Arnold

Van Dikj, T. (2006). Politics, Ideology, and Discourse. Elsevier Ltd.

http://thehill.com/blogs/pundits-blog/presidential-campaign/291498-fulltranscript-donald-trumpaddresses-radical. Retrieved $28^{\text {th }}$ September 2016 